\title{
THE CISG AND PARTY AUTONOMY IN BRAZILIAN INTERNATIONAL CONTRACT LAW
}

Iacyr de Aguilar Vieira

\begin{abstract}
Associate professor of law at Universidade Federal de Viçosa. MG, Brasil. Doctor of law at Université Robert Schuman de Strasbourg, France.
\end{abstract}

\begin{abstract}
This paper focus on the principle of party autonomy in the choice of the law applicable to international contracts under CISG and Brazilian law. It analyses the different possibilities of application of this principle as well as its limits under both legal systems.
\end{abstract}

Keywords: CISG - International contracts - International sales contracts - Vienna Convention.

\section{INTRODUCTION}

The proposed subject for my contribution ${ }^{1}$ suggests an approach under two perspectives: the examination in the light of the Vienna Convention (First part) and the examination in the light of national law systems, for the purposes of this essay, the Brazilian law system (Second part).

\section{FIRST PART}

\section{THE CISG AND PARTY AUTONOMY}

Freedom of contract constitutes the main foundation of the Uniform Law presented by the United Nations Convention on Contracts for the International Sale of Goods (CISG), which has the nature of supplementary law. Under this perspective, the freedom is characterized by the exclusion or by the voluntary submission of a sales contract to the Uniform $\operatorname{Law}^{2}(\mathrm{~A})$.

1 This paper reveals the essential content of my contribution during « The CISG and Party Autonomy in Contract Law », pannel on 30 April 2010, by CISG-Brasil.Net Conference, São Paulo, I Seminário Internacional "O Brasil e a CISG”, in 29 and 30 April 2010. The oral style of the conference was preserved. The footnotes and bibliographical references here are limited to the essential.

2 It is very important to take into account the assertion contained in the UNCITRAL Digest 2012 (p. 33), in regard to party autonomy in international contracts: « By allowing the parties to exclude the Convention or derogate from its provisions, the drafters affirmed the principle that 
The application of the Vienna Convention as a result of contractual freedom - different situations that lead to the application of the CISG (B).

\section{A. FREEDOM OF CONTRACT}

By adopting the opt-out system (2), the Vienna Convention is naturally applicable where all its applicability conditions are fulfilled (1). Contractual freedom, however, may exclude the application of the Uniform Law or lead to its application even in situations where it would not normally be applicable. (3).

The limits of this freedom are set out in Article 6 of the Vienna Convention (4). This norm authorizes parties to exclude the application of the Vienna Convention, to derogate from its provisions or to vary their effects:

"The parties may exclude the application of this Convention or, subject to article 12, derogate from or vary the effect of any of its provisions".

This Article contains the recognition of the optional nature of the Convention and the main role that party autonomy plays in international trade and, in particular, in international contracts of sale. This affirmative is found in the comments to article 6 of the Recueil analytique de jurisprudence, it is also illustrated by several decisions enshrined in the CLOUT system and recognized by different Vienna Convention commentators.

The supplementary nature of the Uniform Law also allows the Contracting Parties to voluntarily submit their contract to its provisions, and they can trigger its application, even if the Uniform Law is presented, at first, as inapplicable.

Therefore, it is important to analyze party autonomy as far as the exclusion of the application of the Vienna Convention is concerned, the derogation from and the modification of some of its provisions, before analyzing the different types of application of the Vienna Convention as a consequence of the contractual freedom conferred upon the contracting parties.

\section{Applicability Conditions of the CISG}

The field of application of the CISG is provided for in Articles

the primary source of rules for international sales contract is party autonomy. Thus the drafters clearly acknowledged the Convention's non-mandatory nature and the central role that party autonomy plays in international commerce - specifically, in international sales ». 
1 to 6 CISG, and the conditions of applicability of the Convention are presented in its Article 1.

This Article presents, in its item 1, letter a, the criterion based on reciprocity, which means that the Convention applies when the contracting parties have their places of business in Contracting States; hence, it establishes the principle of autonomous or direct application of the Convention.

Article First, item 1, letter b, presents a rule of distribution - it is not, in essence, a private international law rule; it requires the application of rules regarding conflicts of Law of the place of the judge and the designation of the Law of a Contracting State (SCHELECHTRIEM and WITZ, p. 18). As a part of the legal system of a Contracting State, the Vienna Convention presents itself as the applicable law to international contracts for sales of goods, as a result of the distribution operated ex vi of Article 1.1, letter b.

\section{The Freedom of Contract Principle in the Light of the Opt-out System}

By adopting the opt-out system, the Convention presents the potential application of its rules. The parties may, however, exclude expressly or implicitly the application of the Vienna Convention, and this conventional exclusion may be manifested through different forms.

Expressly, the exclusion may occur by the adoption of a clause in the following terms: "the present contract is not governed by the Vienna Convention", without a correlative choice of applicable law.

The exclusion may also occur by the insertion of a clause in that nature in the general conditions, which are validly incorporated into the contract.

The express exclusion may result from the indication by the parties of the applicability of the law of a non-Contracting State, which might be cause for surprise as, everyday, new members join the circle of Contracting States.

The exclusion may occur in a phase after the conclusion of the contract: the litigation phase (Oberlandesgerich Hamm, 6 May 1998 CLOUT case No. 278).

The exclusion of application of the Uniform Law may also result in the conventional submission of the contract to other rules of law, besides the Vienna Convention.

Implicitly, the exclusion of application of the Vienna Convention is also possible, although Article 6 does not mention this possibility, as did ULIS in its Article 3. The Article's silence is explained by the concern of the Vienna Convention drafters to prevent judges from accepting the exclusion too hastily, thereby compromising 
the application of the Uniform Law.

As stated in the doctrine, the designation of an arbitral tribunal located in a State not party to the Vienna Convention should not be interpreted, by itself, as an implied exclusion of the Uniform Law.

The use of general conditions of sale or of purchase drafted before the entry into force of the Uniform Law, and in conformity with domestic law, should not, in the same way, produce the effect of an implied exclusion.

\section{Applicability of the Freedom of Contract Principle:}

\section{a. The submission of the contract to the law of a Contracting State}

The designation by the parties of a domestic Law, by observing the applicable rules of conflict of laws, does not mean, with the exception of particular circumstances, that the parties have chosen the Law applicable to internal sales.

This designation includes the Vienna Convention when its applicability conditions are met. For the choice of a domestic Law to represent the exclusion or the disregard of the Vienna Convention, it is necessary that it clearly indicate that the parties intended to exclude the application of the Uniform Law. The dominant international case law understands that the choice of a Contracting State's Law includes the Uniform Law, unless the parties have expressed their intent of applying domestic Law. As an example, consider the direct indication of an article or of several articles of a given Civil Code, related to the warranty of latent defects (SCHELECHTRIEM and WITZ, p. 17).

One should also consider that the CISG does not regulate all aspects of a contract of sale, which require the application of domestic Laws (see, v.g., Articles 4 and 5). That is the case for the validity of the contract or of any of its clauses, the prescription (limitation periods), the transfer of credit or the set off, when operated inside a contract of sale.

What should also be kept in mind is that the interpretation of the parties intentions will and declarations must be made in the light of Article 8 of the CISG, in an autonomous way, independently from national conceptions, as indicated in Article 7 of the CISG.

\section{b. The choice of the Law of a non-Contracting State}

- Effect: Exclusion of the Vienna Convention? 
When the contracting parties submit the contract of sale to the Law of a non-Contracting State, does that choice of Law exclude the application of the Vienna Convention? It is necessary to verify, first, if the applicable Law clause is effective, considering the rules regarding conflicts of Law.

\section{c. General conditions of sale or of purchase}

In principle, the exclusion of the Vienna Convention is equally admissible by provisions of the General Conditions of sale or purchase, as long as these general conditions are within the contractual boundaries.

It may occur, however, that a clause of exclusion is considered not to be contained within the contractual boundaries, or that the general conditions were drafted before the entry into force of the CISG in the Law system indicated by the parties. The difficulty lies in determining the extent of the clause of exclusion in this manner.

It may also occur that the contract is submitted to new general conditions, excluding the CISG, while the parties have, until then, concluded and performed their contracts under its rules.

\section{d. The denial or rejection, or the modification of the Uniform Law of contracts of sale}

The parties may exclude the application of the Uniform Law by other means, aside from the choice of the legal system of a nonContracting State.

The parties are allowed to exclude the application of the CISG by using an express clause. They are also free, in virtue of Article 6 , to modify or to complete the Uniform Law making use of, v.g., the INCOTERMS, the UNIDROIT principles regarding international commercial contracts, or even the lex mercatoria.

Potential limits to the effectiveness of these clauses may result from the domestic Law applicable to contracts of sale. Indeed, the exam of the validity of the contractual clauses is not within the scope of the CISG (vide Article 4).

\section{Limits to Exclusion}

Although drafted clearly, Article 6 demands some explanations:

It is important to highlight that, by providing for different situations where the parties freely determine the Law applicable to their contract, Article 6 presents a distinction between the total exclusion of application of the CISG and the derogation of certain of its provisions.

For the first situation, the CISG does not present any restriction, 
while for the derogation from some of its provisions the Convention imposes a limit that consists in the observation of Article 12. In other words: when a party to a contract bound by the Convention has its place of business or residence in a State that has made a reservation in virtue of Article 96, the parties cannot derogate from Article 12 or modify its effects.

That is, apparently, the only limit imposed by the CISG to freedom of contract by the CISG regulated. According to Article 12, the provisions of Article 11, Article 29 or of the second part of the Convention, authorizing a form other than written, either for the conclusion of a contract of sale, or its modification or termination by agreement or any offer, acceptance or other indication of intention, does not apply when one of the parties has its place of business or residence in a Contracting State which has made a declaration under article 96 of the CISG.

Article 12 is a mandatory rule of the Convention, which cannot be disposed of by the parties.

In the same way, Articles 89 to 101, which constitute public Law provisions, also cannot be derogated from by the parties, and they impose limits to the material exclusion of the CISG by them. Commentary understands that the provisions of Article 7 of the CISG cannot be derogated from by the parties. These provisions, which present rules of interpretation and gap-filling cannot be disposed by the parties.

\section{B. SITUATIONS INVOLVING CHOICE OF THE CISG BY THE PARTIES}

\section{Assimilation within the limits presented by the rules of conflicts of Law.}

The contracting parties may not only exclude the application of the CISG to its contract, they may also submit to the Uniform Law a contractual operation that is out of its scope, even when it lacks one of the conditions of applicability of the CISG.

Hence, the parties may also trigger the application of the Uniform Law, inapplicable in principle, overcoming the obstacles to the natural application of the Vienna Convention.

The validity of such conventional submission clause cannot be examined in the light of the CISG, which is silent in regards to opting in. Indeed, the CISG does not provide for (in a direct and express manner) that the application of the Convention results on the party autonomy ${ }^{3}$.

3 See JACQUET Jean-Michel, « Le droit de la vente internationale de marchandises : le mélange de sources », In : Souveraineté étatique et marchés internationaux à la fin du 20ème siècle. Mélanges en l'honneur de Philippe KAHN. Université de Bourgogne-CNRS, - vol. 20, Paris : 
It is convenient to focus on the rules of Conflict of Law. Frequently they only allow the parties to choose a domestic Law. That is what happens under the Hague Convention Relating to the Settlement of the Conflicts Between the Law of Nationality and the Law of Domicile, from June, 15th, 1955, the Rome Convention of 1980 relating to contractual obligations and the Rome I Regulation.

Hence, a choice of Law in favor of the CISG, where the conditions are not fulfilled, would be ineffective.

It is important, in that case, to apply the objective proximity criteria and to verify to what extent the contracting parties may derogate from the domestic Law applicable, submitting their contractual operation to the Uniform Law (CISG).

In other words, the Uniform Law may substitute only the supplementary provisions of the domestic Law applicable.

The drafters of the Rome I Regulation, which replaces the 1980 Rome Convention, for the contracts concluded after December 17th, 2009 , intended to make the voluntary submission of contracts to the CISG easier. Indeed, the initial version of the proposition authorized contracting parties to submit their contractual operations to the "rules and principles of the material law of the contracts, recognized at international and community levels". This rule, however, was not accepted in the final text of the Rome I Regulation, although it is present in the Mexico Convention (vide Article 10).

A choice of the contracting parties in favor of the CISG might be conceived to the purpose of the contract of sale of a ship. It is also possible that the CISG is applied in a distribution or framework agreement, with contracts of sale as "sales agreements" contained, therefore, in the scope of the CISG.

Such submission is also conceivable for the purposes of mixed contracts, combining a contract of sale in the scope of the CISG with an operation not in the scope of its material applicability. The parties must, nevertheless, be prudent when the qualification of the contract distances itself from a contract of sale, as the remedies and means provided to the contracting parties in case of absence or failure of performance are established considering goods as the object of the contracts.

Other forms of voluntary submission of contracts to the Vienna Convention ${ }^{4}$.

Litec, Année 2000, p. 75-93, at. p. 89-90.

$4 \mathrm{Ph}$. Kahn, Les Conventions internationales de droit uniforme devant les tribunaux arbitraux, International Uniform Law Conventions, Lex Mercatoria and UNIDROIT Principles, Symposium held at Verona University (4-6 November 1999), Revue de droit uniforme, 2000-1, p.121127, at. p. 122-123. 
a) Designation of the Vienna Convention as lex contractus ${ }^{5}$

b) Reference to the lex mercatoria as the applicable $\mathrm{Law}^{6}$.

\section{c) Reference to the standards, general principles of law and to the usus contractus ${ }^{7}$.}

The arbitrators are allowed to apply the standards ${ }^{8}$ and general principles of law as an integral part of the Vienna Convention. In that sense, we refer to the arbitral award issued in ICC case No. 7331 (1994) ${ }^{9}$. In the arbitral award of ICC case No. 6281 (1989), the arbitrators applied the Vienna Convention as a statute endowed with universal values given the number of contracting states ${ }^{10}$. We also highlight the arbitral award of ICC case No. 9887 (1998), which applies the Vienna Convention by recognizing that it reflects the evolution of international

5 See the arbitration awards ICC ${ }^{\circ} 8213$ and 8769 , which the Vienna Convention was applied because the parties pointed as applicable law the set of rules such as the Vienna Convention. The partial arbitration award rendered in affaire $n^{\circ} 8213$, published In: Bulletin de Cour internationale d'arbitrage de la CCI, Vol. $11 / \mathrm{N}^{\circ} 2$, p. 50-53, at. p. 53, reveals that the parties had designated as applicable law the Uniform Commercial Code and the Vienna Convention. Under the terms of the contract, reproduced by the sentence, the parties agreed the following: “ a) the Purchase Agreement dated [...] was governed by the Law of the State of New Jersey, including New Jersey version of the Uniform Commercial Code ("NJUCC") ; b) the Purchase Agreement date [...] was governed by the United Nations Convention on Contracts for the International Sale of Goods (Vienna, 1980) (“UNISG ") ". See to: H. van Houtte, La convention de Vienne dans la pratique arbitrale de la Chambre de commerce internationale, Bulletin de la Cour internationale d'arbitrage de la CCI, Vol. 11/ $\mathrm{N}^{\mathrm{o}} 2-2^{\circ}$ semestre 2000, p. 22-33.

6 Application of the lex mercatoria. Arbitral award ICC n. 2291/75. The arbitral tribunal has found that: "les parties n'ayant pas pris la précaution de rédiger un contrat formel, il convient d'interpréter leurs volontés et leurs engagements à partir de leurs écrits, et en fonction des principes généraux du droit et de l'équité, qui doivent régir les transactions commerciales internationales ». In : Clunet, 1978, p. 989.

7 See VENEZIANO Anna, «L'application des principes d'UNIDROIT dans la vente internationale », Revue de droit des affaires internationales, N 3/4, 2001, p. 477 - 488. See to MAYER Pierre, «L'application par l'arbitre des conventions internationales de droit privé », In : L'internationalisation du droit, Mélanges en l'honneur de Yvon Loussouarn, Paris : Dalloz, 1994, p. 275-291.

8 See J.-P. Beraudo, « La Convention des Nations Unies sur les contrats de vente internationale de marchandises et l'arbitrage », In : Bulletin de la Cour internationale d'arbitrage de la CCI, Vol. 5/No 1, Mai 1994, (p. 61-65, p. 63-64.

9 Bulletin de la Cour d'Arbitrage de la CCI, 1995, p. 73. J.D.I. 1995, p. 1001-1009 (note D. Hascher). Commentaire A. Mourre, Application of the Vienna International Sales Convention in Arbitration, cit., p. 49.

10 The Hague Kluwer Law International, 1997, p. 409. J.D.I. 1991, p. 1054 (note D. Hascher). Comm. A. Mourre, Application of the Vienna International Sales Convention in Arbitration, cit.,p. 49. 
law and, in particular, of international sales law ${ }^{11}$.

Arbitrators do not hesitate to apply the Vienna Convention as a repertory of international commercial usages. In that sense, an ICC tribunal applied the Vienna Convention to a series of contracts concluded in 1979, even before its entry into force, finding that : " il n'existe aucune meilleure source pour déterminer les usages de commerce prévalant que les termes de la Convention des Nations Unies sur la vente internationale de marchandises du 11 avril 1980 sur base du fait [...]. Ceci étant le cas même si ni le pays du vendeur ni celui de l'acheteur ne sont parties à cette Convention $\rangle^{12}$.

\section{SECOND PART}

\section{THE BRAZILIAN LAW SYSTEM AND THE APPLICABILITY OF THE CISG AS A RESULT OF THE CHOICE OF THE LAW APPLICABLE BY THE PARTIES}

Although the autonomy to choose the Law applicable to contracts is considered a rule of conflict by the majority of Law systems nowadays, either by force of the jurisprudence or of Conventions - see the Hague Convention of 1964 relating to the law applicable to sales of goods, Rome Convention, Rome I Regulation, Mexico Convention -, or by force of express normative provision, such as the Swiss Private International Law Act of December, 18th, 1987, the Codice civile from 1942 , in its article 1322, as well as the statute of reformation of the Italian Private International Law system, of may 31st, 1995 (which was incorporated the Rome Convention in its text), in Brazil there still remains doubt as to its admissibility in the field of state jurisdiction.

For this reason, it is convenient to highlight the possibility of applying the CISG in Brazil by choice of the parties in the field of arbitral jurisdiction, before analyzing the possibility of its application by the state judge.

11 V. Bulletin de la Cour d'Arbitrage de la CCI, Volume 11- № 2, p. 109-110. Comm. A. Mourre, Application of the Vienna International Sales Convention in Arbitration, cit., p. 49. Decision referred to and commented by Iacyr de Aguilar Vieira, L'Applicabilité et l'impact de la Convention des Nations Unies sur les contrats de vente internationale de marchandises au Brésil. Strasbourg : PUS, 2010, p. 220 and sq.

12 Sentence CCI n ${ }^{\circ}$ 5713, Yearbook of Commercial Arbitration, 1990, p. 70. 


\section{A. ARBITRAL JUDGE - IS NOT NECESSARILY BOUND BY THE CONFLICT OF LAWS SYSTEM.}

The party autonomy principle prevails in the choice of the applicable law:

We emphasize Article 2 of the Brazilian Arbitration Act, Federal Statute n. 9.307, of September, 23rd, 1996. This article gives the parties the possibility to choose between arbitration at law and arbitration by equity - and to freely choose the rules of law applicable to the arbitration, while still being bound to observe custom and usage and the demands of public policy. The parties may, also, determine that the award be enacted on the grounds of general principles of law, usage and international trade rules.

The principle of party autonomy to choose the jurisdiction and the law applicable to conflicts submitted to arbitration is also found in conventional instruments adopted by Brazil under the MERCOSUR legal order:

1) The Buenos Aires Protocol relating to International Jurisdiction on contracts matter, concluded in Buenos Aires, on August 5th, 1994, incorporated in Brazil by Decree n. 2.095, on December 17th, 1996.

2) The Agreement on International Trade Arbitration of MERCOSUR, concluded in Buenos Aires on July 23rd, 1998, incorporated in Brazil by Legislative Decree n. 265, on December 29th, 2000 .

3) As lege ferenda, the principle is set forth in the Convention of Mexico from march 17th, 1994 - adopted in the CIDIP V, within the Brazilian Bar Association (OAB); Brazil has signed the Convention, but until the present it was not ratified. Ratification could lead the Brazilian's contracting parties to achieve the same level of autonomy of its commercial partners, therefore opening a safe window to the application of the principle by the State's judges.

\section{B. THE STATE JUDGE}

The state Judge is necessarily bound by the conflict of laws system.

In Brazil, there is no express provision regarding the principle of party autonomy to choose the applicable law. In the Act of Introduction to the Civil Code (now Act of Introduction to the Brazilian Rules) there are only objective elements of connection: lex loci regit actum and lex loci executionis, relating to obligation matters. 
There is no express prohibition to the party autonomy principle. A principle recognized internationally should not be prohibited without a rational justification.

The doctrine finds itself divided in the matter.

There is no jurisprudence from the Superior Courts regarding the matter at present.

We emphasize recent state court decisions, admitting the choice of law applicable to an international contract (this decisions are referred to and commented by Fernanda V. da Costa CERQUEIRA) ${ }^{13}$.

A decision of the 1st Court of Appeals of São Paulo (Tribunal de Alçada) admitted the adoption of the principle of party autonomy by the state judge, when it expressly declared "that there is not any deterrence to the application of the foreign material law, mentioned by the parties in its contract; that the Brazilian Justice can utilize the material law rules to which the parties voluntarily submitted themselves"14.

It is important to indicate that the Court of Appeals of São Paulo (Tribunal de Alçada, before being extinguished by the 45th Constitutional Amendment), examined yet two appeals relating to the determination of the law applicable to international contracts; resonating the major doctrine, this Court admitted the principle of party autonomy, even if in decisions that were not definite: Case Total Energie do Brasil, S.N.C. and others vs. Thorey Invest Negócios $\mathrm{Ltda}^{15}$ and Case R S Components Ltda vs. R S do Brasil Com. Imp. Exp. Cons. Repr. Ltda ${ }^{16}$.

We may also invoke, in favor of the acceptance of the principle of the parties autonomy to choose the applicable law to their contract, the decision enacted by the São Paulo State Tribunal of Justice in the Case Dexbrasil Ltda vs. Navisys Incorporated. In this case, the Tribunal found that the parties did not attempt against private rights or against Brazilian sovereignty by designating another law to govern their contract $^{17}$.

A decision of the Rio de Janeiro State Tribunal of Justice admitted

13 Fernanda V. da Costa CERQUEIRA, « Le régime de détermination de la loi applicable aux contrats conclus par les consommateurs en droit français et brésilien », in: Michel Storck, Gustavo Vieira da Costa Cerqueira, Thales Morais da Costa (dir.), Actes de la Journée d'études Le droit français et le droit brésilien d'aujourd'hui : éléments de comparaison (Droit français et droit brésilien : perspectives comparées), Strasbourg, June 17th, 2008, Paris : Harmattan, 2010).

14 Agravo de Instrumento $\mathrm{n}^{\circ} 46.457$ de 29 de agosto de 2002, $11^{\text {a }}$ Câmara Cível do $1^{\circ}$ Tribunal de Alçada de São Paulo.

$157^{\text {a }}$ Câmara do $1^{\circ}$ Tribunal de Alçada do Estado de São Paulo, Registro N ${ }^{\circ}$ 00.551794-0. Judgment from September 24th, 2002.

$1612^{\text {a }}$ Câmara do $1^{\circ}$ Tribunal de Alçada do Estado de São Paulo, AG N ${ }^{\circ}$ 1.247.070. Judgment from december 18th, 2003.

17 Judgment from June 7th, 2002. Tribunal de Justiça do Estado de São Paulo, $30^{\mathrm{a}}$ Vara Cível de São Paulo. 
directly the principle of party autonomy ${ }^{18}$ and recently, on October 18th, 2007, the São Paulo State Tribunal of Justice reaffirmed its attachment to the principle of parties autonomy to choose the applicable law to their contract, in a judgment regarding the determination of the law applicable to an international trade representation contract ${ }^{19}$.

These State Court's decisions may contribute to a better acceptance of the principle of party autonomy as part of the rules of conflict of laws in Brazilian private international law, as already happens in legal systems of nations that play an active role in contemporary international trade. Upon this acceptance depends equally the application of the Vienna Convention as foreign Law or as material Uniform Law expressly chosen by the parties.

In the absence of the determination of the law applicable to an international contract, or in case of a choice considered not valid, the interpreter or the judge must utilize the other rules of conflict of laws adopted by the domestic Law, which means applying the rules regarding the application of the law in territory, provided for in the Act of Introduction to the Brazilian Rules (art.9 ${ }^{\circ}$ LINDB).

\section{FINAL REMARKS}

While Brazil's accession to the United Nations Convention on Contracts for the International Sale of Goods (CISG) implies the CISG's application regardless of express adoption of the party autonomy principle, it is also certain that it will open the debate as to party autonomy in respect of the parties and will in choosing the law that applies to issues not covered by the CISG and to those expressly set aside by it, as well as on the law applicable to other kinds of international contracts.

Such accession, which gets closer every day ${ }^{20}$, bears as unassailable consequence a renovation of Brazilian private international law, combined with a renovation of domestic contract law, in light of

18 Decision from March 27th, 2007, 15a Câmara Civil do Tribunal de Justiça do Estado do Rio de Janeiro, Agravo de Instrumento $\mathrm{N}^{\circ}$ 2007.002.02431.

19 Tribunal de Justiça do Estado de São Paulo. Decision from October 18th, 2007. Apelação No 7.030.387-6.

20 The adherence of Brazil to the United Nations Convention on Contracts for the International Sale of Goods was approved by the Brazilian National Congress on October 16, 2012, by Legislative Decree n. 538 of October 18, 2012. It is expect, however, the procedure for enactment by the President and the publication in the Official Gazette of the Federal Executive, in accordance with Constitutional rules (Article 49, inc. I, and Article 84, inc. VIII, of the Constitution of the Federal Republic of Brazil, of October 5, 1988). In addition, it is necessary to wait the expiry of twelve months after the deposit of the instrument of adherence, pursuant to Article 99 CISG. 
the modern and rich character of Vienna Convention.

\section{REFERENCES}

BERAUDO Jean-Paul, « Le Congrès Interaméricain sur les Principes d'UNIDROIT », Bulletin de la Cour Internationale d'Arbitrage de la

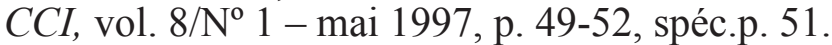

BERAUDO Jean-Paul, « La convention des Nations Unies sur les contrats de vente internationale de marchandises et l'arbitrage ", Bulletin de la Cour internationale d'arbitrage de la CCI, vol. $5 / \mathrm{N}^{\circ} 1$ mai 1994, p. 61-65.

FERRARI Franco, Contrat de vente internationale - Applicabilité et applications de la Convention de Vienne sur les contrats de vente internationale de marchandises, 2e éd. Bâle : Helbing \& Lichtenhahn, Bruxelles : Bruylant, Paris : Forum Européen de la Communication, 2005.

GOLDMAN Berthold, « La lex mercatoria dans les contrats internationaux : réalité et perspectives », Journal de droit international, 1979, p. 475-505.

HOUTTE Hans Van, « La convention de Vienne dans la pratique arbitrale de la Chambre de commerce internationale », Bulletin de la Cour internationale d'arbitrage de la CCI, Vol. $11 / \mathrm{N}^{\circ} 2-2^{\circ}$ semestre 2000, p. 22-34.

JACQUET Jean-Michel, « Le droit de la vente internationale de marchandises : le mélange de sources », Souveraineté étatique et marchés internationaux à la fin du 20ème siècle. A propos de 30 ans de recherche du CREDIMI. Mélanges en l'honneur de Philippe KAHN. Université de Bourgogne-CNRS, - vol. 20, Paris : Litec, Année 2000, p. 75-93.

KAHN Philippe, « Les Conventions internationales de droit uniforme devant les tribunaux arbitraux », International Uniform Law Conventions, Lex Mercatoria and UNIDROIT Principles, Symposium held at Verona University (4-6 November 1999), Revue de droit uniforme, $\mathrm{N}^{\circ}$ 2000-1, p. 121-127.

LAGARDE Paul, «L'approche critique de la lex mercatoria », Le droit des relations économiques internationales, Paris : LITEC, 1982.

MAYER Pierre, " L'application par l'arbitre des conventions internationales de droit privé ", L'internationalisation $d u$ droit, Mélanges en l'honneur de Yvon Loussouarn, Paris : Dalloz, 1994, p. 275-291.

SCHLECHTRIEM Peter, "Introduction », Commentary on the UN Convention of the International Sale of Goods P. SCHLECHTRIEM and I. SCHWENZER (eds), 2nd ed. 2005.

SCHLECHTRIEM Peter et WITZ Claude, Convention de Vienne sur 
les contrats de vente internationale de marchandises, Paris : Dalloz 2008.

VENEZIANO Anna, « L'application des principes d'UNIDROIT dans la vente internationale », Revue de droit des affaires internationales, $\mathrm{N}^{\circ}$ $3 / 4,2001$, p. 477-488.

VIEIRA Iacyr de Aguilar, L'Applicabilité et l'impact de la Convention des Nations Unies sur les contrats de vente internationale de marchandises au Brésil. Strasbourg: PUS, 2010.

VIEIRA Iacyr de Aguilar, « Plaidoyer por uma aplicação da Convenção de Viena de 1980 relativa à compra e venda internacional de mercadorias no Brasil ». In: Estudos de Direito Comparado e de Direito Internacional Privado. Curitiba: Juruá, p. 437- 462.

VIEIRA Iacyr de Aguilar, " La formation du contrat de vente de marchandises en droit Brésilien, en droit Français et dans la Convention de Viena ", Revista da Faculdade de Direito da Universidade Federal do Rio Grande do Sul (Edição Especial em Homenagem à Cooperação Acadêmica UFRGS-França). Porto Alegre: UFRGS/Nova Prova, maio 2008, p. 276-310.

WITZ Claude, « Les vingt-cinq ans de la Convention des Nations Unies sur les contrats de vente internationale de marchandises. Bilans et perspectives », Journal du Droit (Clunet), N 1, 2006, p. 5-25.

WITZ Claude, Les vingt-cinq ans de la Convention des Nations Unies sur les contrats de vente internationale de marchandises - Bilan et perspectives. (tradução de Iacyr de Aguilar Vieira). In: Estudos de Direito Comparado e de Direito Internacional Privado. Curitiba : Juruá, 2011, p. 413-435.

WITZ Claude, « Vente internationale : office du juge et pouvoir des plaideurs d'écarter le droit uniforme », Recueil Dalloz, Jur. Comm. 13 décembre 2001, p. 3607-3614.

WITZ Claude, "Le champ d'application de la Convention de Vienne », La vente éclatée - La diversité des régimes juridiques dans les ventes de marchandises-Colloque de Deauville, 7 et 8 juin 1997 - Revue de jurisprudence commerciale, Numéro spécial dirigé par Michel PEDAMON, novembre 1997, p. 79-97.

WITZ Claude, Les premières applications jurisprudentielles du droit uniforme de la vente internationale, Convention des Nations Unies du 11 avril 1980, Paris : LGDJ, 1995. 